\title{
Irremediable psychiatric suffering in the context of physician assisted death: a Delphi-study.
}

Sisco M.P. van Veen, MD. PhD candidate at the department of Ethics, Law and Humanities at Amsterdam UMC / VUmc \& psychiatrist at GGZ inGeest.

Natalie Evans, PhD. Assistant professor at the department of Ethics, Law and Humanities at the Amsterdam UMC.

Andrea M. Ruissen, MD, PhD. Postdoctoral researcher and psychiatrist at Haaglanden MC. Joris Vandenberghe, MD, PhD. Professor of psychiatry at the University of Leuven.

Aartjan T.F. Beekman, MD, PhD. Professor of psychiatry at Amsterdam UMC / VUmc \& psychiatrist at GGZ inGeest.

Guy A.M. Widdershoven, PhD. Professor of medical philosophy at the department of Ethics, Law and Humanities at Amsterdam UMC / VUmc.

\begin{abstract}
Background Patients with a psychiatric disorder (PPD) are eligible to request physician assisted death (PAD) in a small but growing number of jurisdictions, including the Netherlands and Belgium. For this request to be granted, most of these jurisdictions demand that the patient is competent in her request, and that the suffering experienced is unbearable and irremediable. Especially the criterion of irremediability is challenging to establish in patients with psychiatric disorders.

Aims To establish what criteria Dutch and Belgian experts agree to be essential in characterising irremediable psychiatric suffering (IPS) in the context of PAD.
\end{abstract}

Method A two round Delphi procedure among psychiatrists with relevant experience.

Results Thirteen consensus-criteria were established: five diagnostic and eight treatment-related criteria. Diagnostically, the participants deem a narrative description and attention to contextual and systemic elements necessary. Also, a mandatory second opinion is required. The criteria concerning treatment show that extensive biopsychosocial treatment is needed, and the suffering must be present for several years. Finally, in the case of treatment refusal, the participants agree that there are limits to the number of diagnostic procedures or treatments a patient must undergo.

Conclusions Consensus was found among a Dutch and Belgian expert group on essential criteria for establishing IPS in the context of PAD. These criteria can be used in clinical decision making and can inform future procedural demands and research. 
medRxiv preprint doi: https://doi.org/10.1101/2021.07.19.21260430; this version posted July 22, 2021. The copyright holder for this preprint

(which was not certified by peer review) is the author/funder, who has granted medRxiv a license to display the preprint in perpetuity.

All rights reserved. No reuse allowed without permission.

\section{Introduction}

Patients with a psychiatric disorder (PPD) are eligible to request physician assisted death (PAD) in a small but growing number of jurisdictions, including the Netherlands and Belgium. For this request to be granted, most of these jurisdictions demand that the patient is competent in her request, and that the suffering experienced is unbearable and irremediable. $(1,2)$

The criterion of irremediability is particularly difficult to establish in psychiatric disorders. (3) Retrospective casefile studies of Dutch PPD who died through PAD show if experts disagree on a criterion, it often concerns irremediability. $(1,4)$ A Dutch euthanasia expertise centre recently stated that more clarity on psychiatric irremediability is a priority. (5) A Canadian expert advisory group has also called for more research on the irremediability of psychiatric suffering. (6)

A recent qualitative study on irremediable psychiatric suffering (IPS) among Dutch psychiatrists with experience in establishing IPS in the context of PAD concluded that consensuscriteria are needed to guide current clinical decision-making. (7) Moreover, jurisdictions debating PAD for PPD in the future may benefit from the availability of essential criteria for establishing IPS, developed from the relatively longer practice experiences in the Netherlands and Belgium. If jurisdictions choose to allow PAD for PPD, minimum essential criteria for IPS should also be specified when drafting legislation. Finally, researchers can use criteria of IPS for designing clinical studies on the irremediability of therapy resistant psychiatric disorders and their management.

In this study, we use a Delphi-method to develop expert consensus-criteria for IPS in the context of PAD, focusing on the Netherlands and Belgium where PAD has been permitted in psychiatric practice for over 20 years. Therefore, we address the following research question: what are the criteria that Dutch and Belgian experts agree upon for IPS in the context of PAD for PPD?

\section{Methods}

\section{Ethical approval, data-management, study design and preregistration}

Ethical approval for this study was obtained in the form of a non-WMO declaration from the Medical Ethical Examination Board of Amsterdam UMC / VUmc under registration number D326. Furthermore, a privacy impact assessment was performed, assuring compliance with European privacy laws. For data-management, the survey tool Survalyzer was used, quantitative analysis was performed using SPSS v25.0, and for qualitative analysis Maxqda v18.2.4 was used. Also, the 'Conducting and REporting of DElphi Studies' (CREDES) guidelines were followed. (8) The study protocol was preregistered at the Open Science Framework under project code: qx5hy. 
medRxiv preprint doi: https://doi.org/10.1101/2021.07.19.21260430; this version posted July 22, 2021. The copyright holder for this preprint (which was not certified by peer review) is the author/funder, who has granted medRxiv a license to display the preprint in perpetuity. All rights reserved. No reuse allowed without permission.

\section{Inclusion criteria}

In order to be included in the study (1) participants had to have at least five years of clinical experience as a psychiatrist and (2) they had to have experience with assessing PPD requesting PAD. This could mean that they had investigated a persistent PAD-request from one of their own patients, that they acted as an independent clinical expert in a PAD-procedure, or both. It was not required for them to have actually assisted a patient in dying. No specific exclusion criteria were used.

\section{Participant selection}

First the project group was formed, consisting of the authors of this article, who are Dutch and Belgian experts in PAD in PPD with backgrounds in psychiatry and ethics and different views on PAD for PPD. Through criterion recruitment from the clinical and scientific network of the project group, participants were selected in the Netherlands and Belgium. Diverse perspectives were aimed for by purposely inviting psychiatrists who are known proponents, opponents, or hold a moderate stance on PAD for PPD. Participants in the study were also asked to recommend other experts that met the inclusion criteria (snowballing). An information letter was sent describing that participation will not yield direct benefits and that the main burden is the time investment. Informed consent was obtained from all participants, and everyone gave permission to be acknowledged for their efforts in the final publication, adding to the transparency of the study. Participants were sent an email with a personal link to the online survey. At the beginning of the study, all round one participants were explicitly asked to participate in all subsequent rounds, and during both rounds two reminders were sent.

\section{Survey design and data analysis}

The round one survey was developed during project group meetings using insights from a systematic review and a qualitative interview study among psychiatrists, both on the topic of irremediable psychiatric suffering. $(3,7)$ The criteria were subdivided in three categories: diagnostic criteria, treatment criteria and treatment refusal criteria. First, the participants were asked to give their own definition of IPS. Next, they were asked their opinions on 20 criteria using a 5-point Likert-scale (strongly disagree, disagree, neutral, agree, strongly agree). The participants were encouraged to provide arguments for their ratings in an open comment section. Relevant socio-demographic and professional characteristics were also collected (table 1). Finally, participants were asked whether they would perform PAD for PPD themselves. The survey was validated in a pilot phase, during which three senior psychiatry residents from the Netherlands and Belgium filled out the survey in the presence of the corresponding author using the 'think aloud' approach. (9) 
medRxiv preprint doi: https://doi.org/10.1101/2021.07.19.21260430; this version posted July 22, 2021. The copyright holder for this preprint (which was not certified by peer review) is the author/funder, who has granted medRxiv a license to display the preprint in perpetuity. All rights reserved. No reuse allowed without permission.

After round one, the open definition and accompanying comments for each criterion were coded and categorized using thematic analysis, paying particular attention to indications that the participant had misunderstood any elements of the criteria or desired more details. (10) The Likertscales were analysed using basic descriptive statistics. Consensus was defined as $70 \%$ of the experts agreeing/disagreeing or strongly agreeing/disagreeing with a statement (i.e. the top or bottom two options on the five-point Likert-scale). (11) The round one results were discussed in two project group meetings and summarized in a feedback report (supplement 1 ). The open definitions served as inspiration for additional criteria for round two. When the comments showed that criteria were misunderstood or valuable suggestions were given for wording changes, the criteria were modified and included in round two accompanied by a summary of the comments. If the comments lacked relevant arguments and no substantial changes were suggested, the consensus or dissensus about the criterion was accepted. The round two survey was piloted again on one of the senior psychiatric residents using the 'think aloud' approach.

The results of round two were discussed in a project group meeting and summarized in a feedback report (supplement 2). Using the same standards as round one it was concluded that the wording was sufficiently clear for all criteria, arguments for agreeing or disagreeing were similar to round one and became repetitive, and no substantial new viewpoints were introduced by participants, indicating response stability. (12) Therefore, the outcomes of round two criteria were accepted and no third round was performed.

\section{Results}

\section{Participants}

67 psychiatrists, meeting the inclusion criteria, responded to an invitation to participate and were sent the survey. 53 psychiatrists completed the first round (79\%), of these 47 completed round two (89\% of those responding to round 1 ). Demographic and professional characteristics of participants are shown in Table 1. Of the initial 53 participants, the mean age was 54 and $47 \%$ were female. Of these participants, $75 \%$ worked in the Netherlands, $21 \%$ in Belgium and $4 \%$ in both countries. $91 \%$ had received a PAD-request from one or more of their own patients, $81 \%$ had performed an independent consultation, and $23 \%$ had actually performed PAD due to psychiatric suffering. 
medRxiv preprint doi: https://doi.org/10.1101/2021.07.19.21260430; this version posted July 22, 2021. The copyright holder for this preprint (which was not certified by peer review) is the author/funder, who has granted medRxiv a license to display the preprint in perpetuity. All rights reserved. No reuse allowed without permission.

\begin{tabular}{|c|c|c|}
\hline & $\begin{array}{l}\text { Round } 1 \\
(n=53)\end{array}$ & Round $2(n=47)$ \\
\hline Age, mean (SD) & $54(10)$ & $54(9.9)$ \\
\hline Female respondents (\%) & $25(47)$ & $23(49)$ \\
\hline \multicolumn{3}{|l|}{ Religion (\%) } \\
\hline Non-religious & $42(89)$ & $37(79)$ \\
\hline Christian & $8(15)$ & $7(15)$ \\
\hline Other religion* & $1(2)$ & $1(2)$ \\
\hline No answer & $2(4)$ & $2(4)$ \\
\hline \multicolumn{3}{|l|}{ Country of occupation** (\%) } \\
\hline Netherlands & $40(75)$ & $36(77)$ \\
\hline Belgium & $11(21)$ & $9(19)$ \\
\hline Netherlands and Belgium & $2(4)$ & $2(4)$ \\
\hline Years of clinical experience*** (SD) & $22.3(9.8)$ & $22.4(9.7)$ \\
\hline \multicolumn{3}{|l|}{ Primary workplace (\%) } \\
\hline $1^{\text {st }}$ tier psychiatric practice & $1(2)$ & $1(2)$ \\
\hline $2^{\text {nd }}$ tier psychiatric care facility & $18(34)$ & $16(34)$ \\
\hline General hospital & $8(15)$ & $7(15)$ \\
\hline Forensic psychiatric care facility & $1(2)$ & $1(2)$ \\
\hline $3^{\text {rd }}$ tier psychiatric care facility & $10(19)$ & $9(19)$ \\
\hline University Hospital & $8(15)$ & $6(13)$ \\
\hline Expertise Centre Euthanasia & $5(9)$ & $5(11)$ \\
\hline (Independent) Euthanasia Consultant & $2(4)$ & $2(4)$ \\
\hline \multicolumn{3}{|l|}{ Sub-specialization**** (\%) } \\
\hline Child and adolescent psychiatry & $5(9)$ & $5(11)$ \\
\hline Adult psychiatry & $45(85)$ & $39(83)$ \\
\hline Elderly psychiatry & $10(19)$ & $10(21)$ \\
\hline \multicolumn{3}{|l|}{ Clinical expertise $* * * *(\%)$} \\
\hline Anxiety disorders & $12(23)$ & $10(21)$ \\
\hline Depressive mood disorders & $17(32)$ & $15(32)$ \\
\hline Bipolar disorders & $17(32)$ & $16(34)$ \\
\hline Trauma- and stressor related disorders & $8(15)$ & $6(13)$ \\
\hline Neurobiological development disorders & 9 (17) & $7(15)$ \\
\hline Neurodegenerative disorders & $10(19)$ & 9 (19) \\
\hline Obsessive-compulsive disorders & $11(21)$ & 9 (19) \\
\hline Personality disorders & $18(34)$ & $16(34)$ \\
\hline Schizophrenia and related psychotic disorders & $20(38)$ & $16(34)$ \\
\hline Somatic symptom disorders & $8(15)$ & $6(13)$ \\
\hline Eating disorders & $5(9)$ & $4(9)$ \\
\hline Other psychiatric disorders & $15(28)$ & $13(28)$ \\
\hline \multicolumn{3}{|l|}{ Experience with PAD**** (\%) } \\
\hline Received a PAD-request from a patient under their care & $48(91)$ & $42(89)$ \\
\hline Performed an independent consultation & $43(81)$ & $39(83)$ \\
\hline Have performed PAD themselves & $12(23)$ & $11(23)$ \\
\hline \multicolumn{3}{|l|}{ Views on performing PAD (\%) } \\
\hline Would consider performing PAD & $29(55)$ & $28(60)$ \\
\hline Would not consider performing PAD & $12(23)$ & 9 (19) \\
\hline Unsure about performing PAD & $11(21)$ & $9(19)$ \\
\hline I would rather not answer & $1(2)$ & $1(2)$ \\
\hline \multicolumn{3}{|c|}{$\begin{array}{l}\text { * This option was selected from a list containing all major religions. } \\
* * \text { Since it is possible to life in one country and work in the other, we focused on the country of occupation, rather } \\
\text { than nationality. It is possible for clinicians to work in both countries. } \\
* * * \text { Counted from the moment they became a psychiatrist. } \\
* * * * \text { Categories are not mutually exclusive. }\end{array}$} \\
\hline
\end{tabular}


medRxiv preprint doi: https://doi.org/10.1101/2021.07.19.21260430; this version posted July 22,2021 . The copyright holder for this preprint

(which was not certified by peer review) is the author/funder, who has granted medRxiv a license to display the preprint in perpetuity. All rights reserved. No reuse allowed without permission.

\section{Criteria}

After two Delphi rounds, consensus was reached for 13 criteria, which can be subdivided into 5 diagnostic and 8 treatment-related criteria (table 2). Below we summarize the iterative process resulting in the consensus-criteria.

Table 2: Consensus criteria for irremediable psychiatric suffering in the context of physician assisted death Diagnostic criteria

A. When establishing irremediable psychiatric suffering:

1. A psychiatric diagnosis, as described in the DSM-5, should be established according to applicable guidelines.

2. In addition to the classification according to the DSM-5, a narrative account must be given that includes etiology and pathogenesis.

3. In addition to the descriptive diagnostics according to the DSM-5, it should be standard practice to verify whether there are contextual or systemic factors that cause or maintain the psychiatric complaints.

B. During the PAD-procedure, the diagnosis must be independently confirmed by at least two psychiatrists.

C. There are limits to the number of new diagnostic procedures a patient must undertake before it can be said that the psychiatric suffering is irremediable. For example: a patient or psychiatrist may refrain from further diagnostic procedures on reasonable grounds, such as a long history of illness and treatment.

Treatment criteria

D. If side effects allowed, the indicated drug-treatments should have been adequately performed without leading to a significant reduction in suffering.

E. If side effects allowed and if indicated, electroconvulsive therapy (ECT) should have been attempted for a sufficient length of time without leading to a significant reduction in suffering.

F. Psychotherapeutic treatments indicated by the applicable guideline must have been attempted without leading to a significant reduction in suffering.

G. If there are indications that entering into a repeated psychotherapeutic trajectory is meaningful, this must be offered before irremediable psychiatric suffering can be established. For example: because conditions were sub-optimal in previous therapy.

$\mathrm{H}$. At least one recovery-oriented treatment must have been attempted without leading to a significant reduction in suffering.

I. If necessary, substantial efforts should have been made to improve the patient's social situation without leading to a significant reduction in suffering.

J. Because all reasonable treatments must be tried, the psychiatric suffering must have been present for several years before irremediable psychiatric suffering can be established.

K. There are limits to the number of treatments a patient must undergo before psychiatric suffering can be considered irremediable. For example, a patient or psychiatrist may refrain from further treatment on reasonable grounds, such as a long history of illness and treatment or the prospect of serious side effects.

\section{Open definition}

At the beginning of round one the participants were asked to give an open definition of IPS in the context of PAD. 52 participants gave detailed definitions. Through thematic analysis, recurrent themes were identified which are summarized below. A full report of the qualitative analysis can be found in supplement one.

Most participants' definitions specified that a psychiatric disorder should cause suffering which is persistent, long lasting, chronic or constant. Also, almost all definitions contained a criterion that the prognosis should be poor, or as one participant defines it: 
medRxiv preprint doi: https://doi.org/10.1101/2021.07.19.21260430; this version posted July 22, 2021. The copyright holder for this preprint (which was not certified by peer review) is the author/funder, who has granted medRxiv a license to display the preprint in perpetuity. All rights reserved. No reuse allowed without permission.

"[IPS is] severe suffering that stems from a psychiatric disorder and cannot be alleviated by any available treatment options." - P16, Dutch, age 50, has experience with PAD as an independent expert.

Various participants added that extensive treatment must have been tried and failed. Several emphasized the importance of 'finishing the treatment-protocol' or 'trying all evidence-based treatments' without relief of suffering. Others explicated that only reasonable treatment options can be demanded from the patient. One participant captured both of these perspectives, stating:

"Subjectively severe suffering linked to one or more psychiatric diagnoses for which the various treatment options advised by guidelines and accepted within reasonable limits by the patient have been exhausted."- P31, Belgian, 60, has experience with PAD as an independent expert.

The themes 'persistence of suffering', 'poor prognosis' and 'failed treatment' led to two new criteria for round two (see section on round two criteria below).

\section{Round one criteria}

Round one was subdivided in diagnostic criteria, treatment-related criteria and treatment refusal criteria (table 3). Eight of 20 criteria reached consensus, three of which were diagnostic criteria (table 2: $A 1, A 3$ and $B$ ), five were treatment criteria (table 2: D, E, F, H \& I), none of the treatment refusal criteria reached consensus.

Three of five diagnostic criteria reached consensus in the first round (table 3). The accompanying comments indicated these criteria were sufficiently clear and that no substantial new viewpoints were introduced in the comments. These were not, therefore, repeated in round two. Two diagnostic criteria that did not reach consensus were included in round two after rephrasing guided by the comments (tables 3 and 4).

Of the eight initial treatment criteria, five reached consensus in the first round (table 3). From the comments it was clear that all criteria were understood and these were not repeated in round two. Three other criteria did not reach consensus and were adapted based on participants' comments and repeated in round two (tables 3 and 4).

None of the treatment refusal criteria reached consensus. This appeared to be due to the formulation of the criteria: many participants commented that it is certainly possible that the suffering is irremediable when the patient does not cooperate, but that the irremediability cannot be established in this case. The criteria were reformulated in round two (table 4). 
medRxiv preprint doi: https://doi.org/10.1101/2021.07.19.21260430; this version posted July 22,2021 . The copyright holder for this preprint (which was not certified by peer review) is the author/funder, who has granted medRxiv a license to display the preprint in perpetuity. All rights reserved. No reuse allowed without permission.

Table 3: Likert-scale scores of round 1 criteria.

\begin{tabular}{|c|c|c|c|}
\hline Diagnostic criteria & $\begin{array}{l}\text { Disagree / } \\
\text { strongly } \\
\text { disagree } \\
\end{array}$ & $\begin{array}{l}\text { Agree / } \\
\text { strongly } \\
\text { agree }\end{array}$ & $\begin{array}{l}\text { Action after analysing the } \\
\text { comments }\end{array}$ \\
\hline $\begin{array}{l}\text { A psychiatric diagnosis, as described in the DSM-5, should } \\
\text { be established according to applicable guidelines. }\end{array}$ & $13 \%$ & $83 \%$ & Accepted \\
\hline $\begin{array}{l}\text { During the PAD-procedure the diagnosis must be } \\
\text { independently confirmed by at least two psychiatrists. }\end{array}$ & $8 \%$ & $83 \%$ & Accepted \\
\hline $\begin{array}{l}\text { In addition to the descriptive diagnostics according to the } \\
\text { DSM-5, it should be standard practice to verify whether } \\
\text { there are contextual or systemic factors that cause or } \\
\text { maintain the psychiatric complaints. }\end{array}$ & $0 \%$ & $100 \%$ & Accepted \\
\hline $\begin{array}{l}\text { Broad psycho-diagnostic testing, including personality } \\
\text { testing, should be the standard, unless the psychiatrist } \\
\text { provides clear reasons why it is not necessary. }\end{array}$ & $36 \%$ & $41 \%$ & $\begin{array}{l}\text { Rephrased without the } \\
\text { words 'broad' and } \\
\text { 'standard' }\end{array}$ \\
\hline $\begin{array}{l}\text { In addition to the descriptive diagnostics according to the } \\
\text { DSM-5, a formulation must be drawn up for each patient } \\
\text { based on a psychotherapeutic model relevant to the } \\
\text { disorder. }\end{array}$ & $30 \%$ & $43 \%$ & $\begin{array}{l}\text { Changed 'a psycho- } \\
\text { therapeutic model' to 'a } \\
\text { narrative account' }\end{array}$ \\
\hline Treatment criteria & $\begin{array}{c}\text { Disagree } \\
\text { or strongly } \\
\text { disagree } \\
\end{array}$ & $\begin{array}{l}\text { Agree or } \\
\text { strongly } \\
\text { agree }\end{array}$ & $\begin{array}{l}\text { Action after analysing the } \\
\text { comments }\end{array}$ \\
\hline $\begin{array}{l}\text { If side effects allow it, the indicated drug-treatments } \\
\text { should be adequately performed without leading to a } \\
\text { significant reduction in suffering. }\end{array}$ & $0 \%$ & $98 \%$ & Accepted \\
\hline $\begin{array}{l}\text { If side effects allow it and if indicated, ECT should have } \\
\text { been attempted for a sufficient length of time without } \\
\text { leading to a significant reduction in suffering. }\end{array}$ & $9 \%$ & $79 \%$ & Accepted \\
\hline $\begin{array}{l}\text { Psychotherapeutic treatments indicated by the applicable } \\
\text { guideline must have been attempted without leading to a } \\
\text { significant reduction in suffering. }\end{array}$ & $2 \%$ & $92 \%$ & Accepted \\
\hline $\begin{array}{l}\text { If necessary, substantial efforts should be made to } \\
\text { improve the patient's social situation without leading to a } \\
\text { significant reduction in suffering. }\end{array}$ & $0 \%$ & $92 \%$ & Accepted \\
\hline $\begin{array}{l}\text { At least one recovery-oriented treatment must have been } \\
\text { attempted without this leading to a significant reduction in } \\
\text { suffering. }\end{array}$ & $8 \%$ & $72 \%$ & Accepted \\
\hline $\begin{array}{l}\text { When indicated, psychosurgical treatment (such as DBS) } \\
\text { must have been attempted without significantly reducing } \\
\text { suffering. }\end{array}$ & $39 \%$ & $32 \%$ & $\begin{array}{l}\text { Changed 'attempted' to } \\
\text { 'offered' }\end{array}$ \\
\hline $\begin{array}{l}\text { If indicated, at least one acceptance-oriented } \\
\text { psychotherapy must have been attempted without leading } \\
\text { to a significant reduction in suffering before it can be } \\
\text { considered irremediable. }\end{array}$ & $9 \%$ & $60 \%$ & $\begin{array}{l}\text { Changed 'before it can be } \\
\text { considered irremediable' to } \\
\text { 'before IPS can be } \\
\text { established' }\end{array}$ \\
\hline $\begin{array}{l}\text { Indicated psychotherapeutic treatments that were } \\
\text { ineffective in the past, should be repeated without leading } \\
\text { to a significant reduction in suffering. }\end{array}$ & $51 \%$ & $17 \%$ & $\begin{array}{l}\text { Changed 'demanded' to } \\
\text { 'offered' and added that } \\
\text { therapy should only be } \\
\text { repeated 'if there are } \\
\text { indications that this is } \\
\text { useful' }\end{array}$ \\
\hline Treatment refusal criteria & $\begin{array}{l}\text { Disagree } \\
\text { or strongly } \\
\text { disagree }\end{array}$ & $\begin{array}{l}\text { Agree or } \\
\text { strongly } \\
\text { agree }\end{array}$ & $\begin{array}{l}\text { Action after analysing the } \\
\text { comments }\end{array}$ \\
\hline $\begin{array}{l}\text { If a patient does not want to participate in the diagnostic } \\
\text { process, there can be no irremediable psychiatric } \\
\text { suffering. }\end{array}$ & $26 \%$ & $49 \%$ & $\begin{array}{l}\text { Rephrased to 'there are } \\
\text { limits to the number of } \\
\text { diagnostic procedures a } \\
\text { patient must undertake' }\end{array}$ \\
\hline $\begin{array}{l}\text { When a patient refuses the abovementioned drug- } \\
\text { treatments, the suffering is not irremediable. }\end{array}$ & $23 \%$ & $53 \%$ & $\begin{array}{l}\text { Merged all criteria into one } \\
\text { more generic criterion }\end{array}$ \\
\hline $\begin{array}{l}\text { When a patient refuses the abovementioned ECT, the } \\
\text { suffering is not irremediable. }\end{array}$ & $34 \%$ & $36 \%$ & $\begin{array}{l}\text { about treatment and } \\
\text { changed the wording to }\end{array}$ \\
\hline
\end{tabular}


medRxiv preprint doi: https://doi.org/10.1101/2021.07.19.21260430; this version posted July 22, 2021. The copyright holder for this preprint (which was not certified by peer review) is the author/funder, who has granted medRxiv a license to display the preprint in perpetuity. All rights reserved. No reuse allowed without permission.

\begin{tabular}{|c|c|c|c|}
\hline $\begin{array}{l}\text { When a patient refuses the abovementioned psycho- } \\
\text { surgical treatment, the suffering is not irremediable. }\end{array}$ & $60 \%$ & $21 \%$ & \multirow{4}{*}{$\begin{array}{l}\text { 'there should be limits to } \\
\text { the number of treatments a } \\
\text { patient can be asked to } \\
\text { undergo' }\end{array}$} \\
\hline $\begin{array}{l}\text { When a patient refuses the abovementioned } \\
\text { psychotherapy, the suffering is not irremediable. }\end{array}$ & $17 \%$ & $57 \%$ & \\
\hline $\begin{array}{l}\text { When a patient refuses the abovementioned acceptance- } \\
\text { oriented psychotherapy, the suffering is not irremediable. }\end{array}$ & $23 \%$ & $47 \%$ & \\
\hline $\begin{array}{l}\text { When a patient refuses the abovementioned repetition of } \\
\text { psychotherapy, the suffering is not irremediable. }\end{array}$ & $47 \%$ & $11 \%$ & \\
\hline
\end{tabular}

\section{Round two criteria}

The second round contained nine criteria (table 4). The open definition in round one inspired two new criteria in round two. Of these, one reached consensus (table 2: criterion J). Two diagnostic criteria reached consensus (table 2: criteria A2 and C). Out of three criteria concerning treatment, two reached consensus (table 2: criteria $\mathrm{G}$ and $\mathrm{K}$ ). The comments showed that all criteria were well understood and therefore both the dissensus and the consensus that was found was regarded as valid and no new round was started.

\begin{tabular}{|c|c|c|c|}
\hline Diagnostic criteria & $\begin{array}{l}\text { Disagree } \\
\text { or strongly } \\
\text { disagree }\end{array}$ & $\begin{array}{l}\text { Agree or } \\
\text { strongly } \\
\text { agree }\end{array}$ & $\begin{array}{l}\text { Action after } \\
\text { analysing the } \\
\text { comments }\end{array}$ \\
\hline $\begin{array}{l}\text { Structured psycho-diagnostic testing, including personality testing } \\
\text { when relevant, should be performed, unless the psychiatrist } \\
\text { provides clear reasons why it is not necessary. }\end{array}$ & $32 \%$ & $55 \%$ & Accepted \\
\hline $\begin{array}{l}\text { When establishing irremediable psychiatric suffering a narrative } \\
\text { account must be given, that includes etiology and pathogenesis, in } \\
\text { addition to the classification according to the DSM- } 5 \text {. }\end{array}$ & $2 \%$ & $91 \%$ & Accepted \\
\hline $\begin{array}{l}\text { There are limits to the number of new diagnostic procedures a } \\
\text { patient must undertake before it can be said that the psychiatric } \\
\text { suffering is irremediable. } \\
\text { For example: a patient or psychiatrist may refrain from further } \\
\text { diagnostic procedures on reasonable grounds, such as a long } \\
\text { history of illness and treatment. }\end{array}$ & $6 \%$ & $81 \%$ & Accepted \\
\hline Treatment criteria & $\begin{array}{l}\text { Disagree } \\
\text { or strongly } \\
\text { disagree }\end{array}$ & $\begin{array}{l}\text { Agree or } \\
\text { strongly } \\
\text { agree }\end{array}$ & $\begin{array}{l}\text { Action after } \\
\text { analysing the } \\
\text { comments }\end{array}$ \\
\hline $\begin{array}{l}\text { Because it is often difficult to establish a reliable prognosis, the } \\
\text { judgment about non-remediable psychiatric suffering must be } \\
\text { based on the failure of treatment in the past. }\end{array}$ & $11 \%$ & $66 \%$ & Accepted \\
\hline $\begin{array}{l}\text { Because all reasonable treatments must be tried, the psychiatric } \\
\text { suffering must be present for several years before irremediable } \\
\text { psychiatric suffering can be established. }\end{array}$ & $15 \%$ & $81 \%$ & Accepted \\
\hline $\begin{array}{l}\text { If indicated, psychosurgery (such as DBS) must be discussed and } \\
\text { offered to the patient before irremediable psychiatric suffering } \\
\text { can be established. }\end{array}$ & $28 \%$ & $62 \%$ & Accepted \\
\hline $\begin{array}{l}\text { If indicated, at least one acceptance-oriented psychotherapy must } \\
\text { have been attempted without leading to a significant reduction in } \\
\text { suffering before irremediable psychiatric suffering can be } \\
\text { established. }\end{array}$ & $13 \%$ & $66 \%$ & Accepted \\
\hline $\begin{array}{l}\text { If there are indications that entering into a repeated } \\
\text { psychotherapeutic trajectory is meaningful, this must be offered } \\
\text { before irremediable psychiatric suffering can be established. }\end{array}$ & $4 \%$ & $70 \%$ & Accepted \\
\hline
\end{tabular}


medRxiv preprint doi: https://doi.org/10.1101/2021.07.19.21260430; this version posted July 22, 2021. The copyright holder for this preprint (which was not certified by peer review) is the author/funder, who has granted medRxiv a license to display the preprint in perpetuity. All rights reserved. No reuse allowed without permission.

\begin{tabular}{|l|c|c|}
\hline $\begin{array}{l}\text { For example: because conditions were sub-optimal in previous } \\
\text { therapy. }\end{array}$ & & \\
\hline $\begin{array}{l}\text { There are limits to the number of treatments a patient must } \\
\text { undergo before it can be referred to as irremediable psychiatric } \\
\text { suffering. }\end{array}$ & $11 \%$ & $81 \%$ \\
$\begin{array}{l}\text { For example, patient or psychiatrist may refrain from further } \\
\text { treatment on reasonable grounds, such as a long history of illness } \\
\text { and treatment and / or the prospect of serious side effects. }\end{array}$ & Accepted \\
\hline \multicolumn{2}{|l|}{ DSM-5 = Diagnostic statistical manual - fifth edition | DBS = deep brain stimulation } \\
\hline
\end{tabular}

\section{Discussion}

Through a modified Delphi-method, 13 expert consensus-criteria for IPS in the context of PAD were identified, regarding diagnosis and treatment.

\section{Diagnostic criteria}

Participants considered a DSM classification necessary when determining IPS, but even more participants considered the presence of a narrative description and attention to the contextual and systemic elements necessary. These criteria are in line with clinical guidelines describing best practice in psychiatric evaluation. $(13,14)$ The criteria imply that a certain degree of individual interpretation will always be part of the decision-making process concerning IPS in the context of PAD. Further deliberation should focus on what levels of individual interpretation are justifiable. (15)

All participants agreed that a mandatory second opinion should be a criterion of IPS in the context of PAD. This endorses the current due diligence procedures in the Netherlands and Belgium. (16-18) Furthermore, a second opinion can mitigate the risk of interpretative differences.

Policymakers from other jurisdictions should take this insight into account when developing their respective due diligence procedures for psychiatric PAD.

The participants also agree that, although there must be evidence of a substantial clinical history (described in detail below), there should be limits to the number of diagnostic procedures a patient has to undergo before IPS can be established. Especially when this patient has a long history of illness and treatment. This criterion suggests that if the patient refuses certain diagnostic procedures, it does not automatically mean that IPS cannot be established. It may be justified to only demand additional diagnostic procedures, such as neuropsychological or personality testing, when there is a reasonable chance that this will lead to new treatment options.

\section{Treatment criteria}

The participants agree that substantial treatments have to have failed before IPS can be established. This is in line with earlier studies. $(3,7,19)$ 
medRxiv preprint doi: https://doi.org/10.1101/2021.07.19.21260430; this version posted July 22, 2021. The copyright holder for this preprint (which was not certified by peer review) is the author/funder, who has granted medRxiv a license to display the preprint in perpetuity. All rights reserved. No reuse allowed without permission.

The participants also agree that, because all reasonable treatments must be tried, the suffering should be present for several years. This criterion reflects the notion that persistence of suffering is not only time dependent but also treatment dependent. (20) Implementation of this criterion as a due diligence requirement might provide clarity for patients and regulators about the high threshold of irremediability in the context of PAD for PPD. It may also be relevant for distinguishing PAD-requests from impulsive suicidality. (21)

The results also show that experts take both biological and psychological treatments, and social interventions, into account when establishing IPS. This is in line with the biopsychosocial model of psychiatric suffering and treatment, which was introduced by George Engel in 1977, and is still highly influential in contemporary psychiatry. (22) In the context of PAD it can serve as a helpful framework to assess individual treatment criteria.

Regarding the biological treatments, there is consensus that medication and ECT should have been tried, but not psychosurgery. Based on the comments, two main reasons for dissensus emerge: participants find psychosurgery too experimental, too invasive, or both. This shows that effectiveness and proportionality should be taken into account when deciding on treatment criteria.

Participants also agree that appropriate psychotherapeutic treatments must have failed before IPS can be established. Psychiatrists especially supported repetition of psychotherapy if there are indications that earlier therapy was 'performed inadequately'. This criterion should be used with caution, as it is difficult to reliably evaluate the quality of earlier psychotherapy, and knowledge about the efficacy of repeated psychotherapy for therapy-resistant psychiatric complaints is lacking. $(7,23)$ There was no consensus regarding the criterion that acceptance-based therapy should be attempted. This is at odds with the suggestion that working towards acceptance of suffering can be seen as a subsidiary option to psychiatric PAD. (3)

The participants consider social interventions, including recovery-oriented approaches, important in the context of PAD. Also, if necessary, substantial efforts should be made to improve the patient's social situation. This may be read as support for the often use $d$ argument against PAD stating that when a patient with a psychiatric disorder wants to die, we should improve their situation, not offer PAD. (24) But the criterion also implies that when there is no need for improving social support or if proper support does not reduce suffering, IPS may still be established and PAD may still be justified.

Finally, there was consensus that there should be limits to the number of treatments a patient has to undergo before IPS can be established. This allows for treatment refusal, which is an important theme in the debate about IPS in the context of PAD. (3) However, as none of the specific treatment refusal criteria reached consensus, no conclusions can be drawn regarding what specific psychiatric treatments the patient should undergo before IPS can be established in the context of 
medRxiv preprint doi: https://doi.org/10.1101/2021.07.19.21260430; this version posted July 22, 2021. The copyright holder for this preprint (which was not certified by peer review) is the author/funder, who has granted medRxiv a license to display the preprint in perpetuity. All rights reserved. No reuse allowed without permission.

PAD. The current criterion, that only states that there should be limits, leaves room for interpretive differences between psychiatrists, patients and other stakeholders. This can be seen as an argument for a diligent assessment of IPS, which requires experience and expertise of participants, as well as joint deliberation, in order to apply the criterion to an individual case.

\section{Strengths and weaknesses}

A strength of this study is that we were able to access a substantial group of psychiatrists with ample experience in assessing PAD-requests, and representing different views on psychiatric PAD.

A limitation of a consensus-building Delphi survey is that the structure of the questionnaire is determined by the researchers, and participants' comments are interpreted by the project group, limiting the influence of the participants. Moreover, no widely accepted benchmark exists within the research community of what constitutes an adequate level of consensus. Also, because we had to change the criteria in between rounds we were not able to calculate response-stability for any of our questions, which could have been a valuable addition to the current qualitative analysis of response stability. (12)

\section{Recommendations for practice and research}

We recommend implementing these consensus criteria in the due diligence procedures in the Netherlands and Belgium, in order to contribute to more uniformity and fewer fundamental disagreements when assessing the irremediability of psychiatric suffering in the context of PAD. The criteria should be seen as essential, but not necessarily sufficient, and have to be applied with due expertise.

On a wider scale, we recommend that other jurisdictions which allow PAD for PPD, or are currently discussing options for doing so, will consider the importance of specifying minimum and essential criteria for the establishment or IPS. We hope that the criteria agreed on by Dutch and Belgian experts can be used to inform the development of guidance in other jurisdictions. We recommend that this study is replicated in other countries to see whether similar criteria are agreed upon. We also recommend to explore patient views on irremediability more deeply.

Although the criteria are specifically established for patients requesting PAD, they can serve as inspiration for examining psychiatric irremediability in general. Psychiatry is beginning to understand how to rationally deploy sequential treatment modalities, but when to stop treatment is rarely discussed. This is problematic, because continuing to treat patients if no effect is to be expected could be harmful, especially when coercion and burdensome procedures are used. By reliably establishing that suffering is irremediable, we may recognize further curative treatment as futile and shift to palliative approaches. $(25,26)$ 
medRxiv preprint doi: https://doi.org/10.1101/2021.07.19.21260430; this version posted July 22, 2021. The copyright holder for this preprint (which was not certified by peer review) is the author/funder, who has granted medRxiv a license to display the preprint in perpetuity. All rights reserved. No reuse allowed without permission.

\section{With their permission, we want to acknowledge all participants:}

In alphabetical order: T. van Balkom, A. Batalla, A. Been, A. ten Berg, T. Birkenhäger, D. Bloemkolk, M. van den Bergh, A. Bosmans, L. van Bouwel, G. de Cuypere, L. Dil, A. Dols, R. van Duursen, J. Garcia Barnet, G. Glas, K. Goethals, D. van Grootheest, R. Harbers, O. van den Heuvel, M. de Hert, C. Hoff, J. Hovens, C. Huyser, R. Keet, I. Klijn, F. van Koningsveld, P. Kölling, J. Lenssen, J. Luykx, T. Ingenhoven, P. Naarding, H. van Nuffel, P. Neuteleers, D. Peeters, Y. Roke, R. Rotteveel, L. Tak, E. Thys, P. Schulte, G. Smid, R. Snoeij, E. Spuijbroek, M. Soons, P. Stärcke, G. Steegen, J. Steenmeijer, B. Vandekerkhove, C. Vanmechelen, R. de Veen, I. van der Velden, N. Vulink, J. van Waarde \& D. de Wachter.

\section{References}

1. Kim SYH, de Vries R, Peteet JR. Euthanasia and Assisted Suicide of Patients With Psychiatric Disorders in the Netherlands 2011 to 2014. JAMA psychiatry. 2016;73(4):362-368.

2. Shaffer CS, Cook AN, Connolly DA. A conceptual framework for thinking about physicianassisted death for persons with a mental disorder. Psychol Public Policy, Law. 2016;22(2):14157.

3. van Veen SMP, Ruissen AM, Widdershoven GAM. Irremediable psychiatric suffering in the context of physician assisted death: a scoping review of arguments in the literature. Can J Psychiatry. 2020;65(9):593-603.

4. van Veen SMP, Weerheim FW, Mostert M, van Delden JJM. Euthanasia of Dutch Patients with Psychiatric Disorders between 2015 and 2017. J Ethics Ment Heal. 2018;10.

5. Kammeraat M, Kölling P. Psychiatric patients at the Euthanasia Expertise Center. 2020. [Dutch]

6. Gaind KS. Canada At a Crossroads: Recommendations on Medical Assistance in Dying and Persons With a Mental Disorder. 2020.

7. van Veen SMP, Ruissen AM, Evans N, Widdershoven GAM. Psychiatrist views on physician assisted death for patients with a psychiatric disorder: a qualitative study. Preprint available at: https://doi.org/10.1101/2021.05.15.21257262.

8. Jünger S, Payne SA, Brine J, Radbruch L, Brearley SG. Guidance on Conducting and REporting DElphi Studies (CREDES) in palliative care: Recommendations based on a methodological systematic review. Palliat Med. 2017;31(8):684-706.

9. Priede C, Farrall S. Comparing results from different styles of cognitive interviewing: 'verbal probing' vs. 'thinking aloud.' Int J Soc Res Methodol [Internet]. 2011;14(4):271-87.

10. Brady SR. Utilizing and Adapting the Delphi Method for Use in Qualitative Research. Int J Qual Methods [Internet]. 2015;14(5). 
medRxiv preprint doi: https://doi.org/10.1101/2021.07.19.21260430; this version posted July 22, 2021. The copyright holder for this preprint

(which was not certified by peer review) is the author/funder, who has granted medRxiv a license to display the preprint in perpetuity. All rights reserved. No reuse allowed without permission.

11. Sumsion T. The Delphi Technique: An Adaptive Research Tool. Br J Occup Ther. 1998;61(4):153-6.

12. von der Gracht HA. Consensus measurement in Delphi studies. Review and implications for future quality assurance. Technol Forecast Soc Change. 2012;79(8):1525-36.

13. Silverman JJ. The American Psychiatric Association Practice Guidelines for the Psychiatric Evaluation of Adults - Third edition. 2016.

14. Hengeveld MW. Psychiatric assessment of adults - Second edition. 2015. [Dutch]

15. Berghmans R, Widdershoven G, Widdershoven-Heerding I. Physician-assisted suicide in psychiatry and loss of hope. Int J Law Psychiatry. 2013;36(5-6):436-43.

16. Dutch Regional Euthanasia Review Committees: Code of Practice, English version. 2015. Page 26.

17. Flemish Psychiatry Association. Advice text of the Flemish Association for Psychiatry (VVP) on due care requirements for euthanasia - first edition. 2017. [Dutch]

18. Dutch Association for Psychiatry. Guideline: termination of life on request in patients with a mental disorder - third edition. 2018. [Dutch]

19. Onwuteaka-Philipsen BD, Legemaate J, van der Heide A, van Delden H, Evenblij K, El Hammoud I, et al. Third evaluation of the Termination of Life on Request and Assisted Suicide Review Act. 2017. [Dutch]

20. Demyttenaere K, Van Duppen Z. The Impact of (the Concept of) Treatment-Resistant Depression: An Opinion Review. Int J Neuropsychopharmacol [Internet]. 2018;(July).

21. Pronk R, Willems DL, van de Vathorst S. Do Doctors Differentiate Between Suicide and Physician-Assisted Death? A Qualitative Study into the Views of Psychiatrists and General Practitioners. Cult Med Psychiatry. 2020;45(2), 268-281.

22. Engel GL. The need for a new medical model: a challenge for biomedicine. Science. 1977;196(4286):129-36.

23. van Bronswijk S, Moopen N, Beijers L, Ruhe HG, Peeters F. Effectiveness of psychotherapy for treatment-resistant depression: a meta-analysis and meta-regression. Psychol Med. 2019;49(3):366-79.

24. Vulnerable persons standard [Internet]. 2016. Available from: http://www.vps-npv.ca/

25. Levitt S, Buchman D. Applying futility in psychiatry: a concept whose time has come. J Med Ethics. 2020.

26. Trachsel M, Irwin SA, Biller-andorno N, Hoff P, Riese F. Palliative psychiatry for severe persistent mental illness as a new approach to psychiatry? Definition, scope, benefits, and risks. BMC Psychiatry [Internet]. 2016;16(260):1-6. 